\title{
OPTIMISATION OF OSMOTIC DEHYDRATION OF PLUMS
}

\author{
Ondrej Ponjičan ${ }^{\mathrm{a}}$, Aleksandar Sedlar ${ }^{\mathrm{a}}$, Pavol Findura ${ }^{\mathrm{b}}$, Agnieszka Szparaga $^{\mathrm{c}}$, \\ Sławomir Kocira ${ }^{\mathrm{d}^{*}}$ \\ a Department of Agricultural Engineering, University of Novi Sad, \\ b Department of Machines and Production Biosystems, Slovak University of Agriculture Nitra \\ c Department of Agrobiotechnology, Koszalin University of Technology \\ d Department of Machinery Exploitation and Management of Production Processes, \\ University of Life Sciences in Lublin \\ *Corresponding author: e-mail: slawomir.kocira@up.lublin.pl
}

\begin{tabular}{l}
\hline ARTICLE INFO \\
\hline Article history: \\
Received: January 2019 \\
Received in the revised form: \\
February 2019 \\
Accepted: March 2019 \\
\hline Key words: \\
plums, \\
osmotic dehydration, \\
kinetics, \\
optimisation
\end{tabular}

\begin{tabular}{l} 
ABSTRACT \\
The paper presents kinetics of osmotic dehydration of plums in relation \\
to the treatment time and concentration of sucrose solution. The main \\
aim of the study was polyoptimisation of the preservation process, \\
namely selection of optimal parameters of osmotic dehydration pro- \\
cesses including changes in selected quality indicators. Defining of op- \\
timal conditions of the entire course of preservation may influence lim- \\
itation of consumption of preserving substances (osmotic substances) \\
and reduction of the energy demand. Based on the research which was \\
carried out, it was found that parameters of osmotic dehydration had \\
a significant impact on mass transfer coefficients and physico-chemical \\
indicators of fruit - along with the increase of concentration of osmotic \\
solution and extension of the time of the process, the increase of the \\
investigated sizes was observed. In the second part of the paper, opti- \\
mization of the fruit preservation process was performed. The idea of \\
the objective function consisted in minimization of the difference be- \\
tween the expected values of criteria and the values obtained from the \\
experimental results. For the defined scalar optimization criterion an \\
explicit relation between quality and cost of the product was showed. \\
\hline
\end{tabular}

\section{Introduction}

The osmotic dehydration process consists in removal of water from a material with cell structure (e.g. fruit and vegetables) to reduce water activity (Matusek and Meresz, 2002). Thanks to this method, a phase transition does not take place in a product but a chemical composition changes (dry substance increases, significant changes of water activity (Escriche et al., 2000, Gruda et al. 1999). Thus, the main aim of this technique in food processing is improvement of the quality of the final product, particularly in case of various plant raw materials (Kowalska, 2006; Mayor, 2006; Rastogi, 2002; Soliva-Fortuny and Belloso, 2003).

During osmotic dehydration, multidirectional mass transfer takes place under the influence of the osmotic pressure gradient which form at the borderline of solutions caused by a difference in concentrations (Matusek and Meresz, 2002; Rahman and Perera, 2007). Osmotic dehydration is a mass transition process, which is influenced by many factors. Kinetics 
Ondrej Ponjičan et al.

of this process is described, as a rule, as water loss (WL), solid gain (SG), and mass reduction (Shi, 2008). The total mass transfer during dehydration depends on a large number of factors. By a change of the process conditions, raw materials' properties (characteristic structure) it is possible to obtain a product with a varied level of dehydration and saturation with osmotic substance (Bekele and Ramaswamy, 2010).

Optimisation is a complex activity which aims at finding the best variant of the solution of a given task with keeping all limitations. Even more popular is a belief that optimisation treatments are purposeful and even necessary in present times due to a growth of global competition, consumption, and production in the world with simultaneous drastic reduction of natural resources. Quality, which we want to maximize - always depends on many factors which we call attributes of quality. For a decision-maker and in a specific situation, it may have a varied significance (Tarnowski, 2011).

The first aim of the paper was to define kinetics of osmotic dehydration of plums in relation to the processing time and concentration of sucrose solutions. Whereas, the main objective of the paper was polyoptimisation of the preservation process, namely selection of optimal osmotic dehydration processes including changes of selected quality indicators. Defining of the best conditions of the entire course of preservation may further influence a limitation of consumption of preserving substances (osmotic substances) and reduction of the energy consumption.

\section{Material and research methods}

Research material consisted in 'common plum' (Prunus domestica L.). The investigated variety of plums was obtained from an orchard in Skierniewice where a good horticultural practice is applied (an integrated production method). Harvesting of fruit took place in the following years: 2008, 2009 and 2010 at the end of September. Mature, healthy material with similar dimensions was used in the research. Fruits were assessed on account of cultivar uniformity. Features that completely disqualified the material were any signs of mould, fermentation, infestation, decay. Raw material was initially cleaned to remove organic or mineral contaminations and, to some degree, also superficial microflora. Pedicels and stones were removed from plums by manual drilling. Osmotic dehydration of halves of plums was carried out in sucrose solutions with concentrations: $35,45,55$ and $65 \%$, during 1.5 and $3.0 \mathrm{~h}$, in the temperature of $20^{\circ} \mathrm{C}$. Relation of the raw material mass to the mass of osmotic solution was 1 : 4. Dehydration was carried out in water bath with shaking type Elpin + type 357.

During dehydration, the following values were analysed.

- Water loss (WL);

- Increase of dry mass (SG);

- Efficiency of osmotic dehydration (WL/SG);

Water loss and increment of dry mass in fruit that were osmotically dehydrated were determined based on the following equations (Kowalska, 2009; Panagiotou et al., 1999).

$$
W L=\frac{\left(M_{0}-m_{0}\right)-(M-m)}{m_{0}}\left[\begin{array}{lll}
g & H_{2} O / g & \text { p.s.m }
\end{array}\right]
$$


Optimisation of osmotic...

$$
S G=\frac{M \cdot m-M_{0} \cdot m_{0}}{M_{0} \cdot m_{0}}\left[\begin{array}{lll}
g & \text { s.m. } / g & \text { p.s.m. }
\end{array}\right]
$$

where:

$\mathrm{m}_{\mathrm{E}} \quad$ - initial weight of a sample before dehydration, $(\mathrm{g})$

M - mass of a sample after time $t$ of osmotic dehydration, $(\mathrm{g})$

$\mathrm{m}_{0} \quad$ - initial content of dry mass, $(\%)$

M - content of dry mass after time t of osmotic dehydration, (\%)

p.s.m. - initial content of dry mass in raw material, (g)

Determination of the dry substance content was carried out according to PN-90/A75101.03 and PB - HŻ - CH/03 Issue 2 as of 9 July 2009 with a dryer BF 1151 by Binder with forced air circulation. Determination of the total extract content was performed according to PN-EN 12143:2000 and PN-90/A-75101.02, with the use of a laboratory refractometer RL3. Determination of the content of reducing saccharides with Bertrand method was performed according to PN-A-75101-07:1990 and PB - HŻ - CH/07 Issue 2 as of 9 July 2009. Physico-chemical indicators in each of three samples were determined as average values of measurements set in a tabular form and the obtained results were subjected to statistical analysis in Statistica program (version 10.0) and program Analysis of variance of Experiments Version 2.1. (University of Technology and Life Sciences in Bydgoszcz). Interpolation of obtained results and polyoptimisation was made with the use of Matlab program (version 7.0). The purpose of polyoptimisation was determination of the process settings at which the best quality product may be obtained at the simultaneous reduction of costs. Optimisation criteria were divided into two groups: criteria related to the quality of the product and criteria related to the production cost. The first criterion of quality was content of extract $\mathrm{k}_{1}$. Extract, according to a definition is a sum of all soluble and volatile solutions to the temperature of $100^{\circ} \mathrm{C}$ included in a product. It was assumed that the optimal value of this criterion should be the highest. The second criterion was the content of reducing saccharides $\mathrm{k}_{2}$. It was assumed that it should be the highest. The third criterion was a dry substance content in product $\mathrm{k}_{3}$. The content of dry mass is related to the amount of water in a product which directly translates into its shell life. Dry mass content should be thus the highest since then the most durable product is obtained (Bartosik et al., 2011, Plawgo et al., 2009). The last criterion of the quality was the coefficient of osmotic dehydration intensity $\mathrm{k}_{4}$. A ratio of water loss and solid gain $(\mathrm{WL} / \mathrm{SG})$ is one of the indicators used for assessment of the osmotic dehydration efficiency. It is desirable to have a considerable reduction of water loss and high values of this coefficient indicate a good efficiency of the dehydration process (Kowalska, 2001). Shifting to cost criteria, firstly costs related to the time of osmotic dehydration should be mentioned. It is obvious that dehydration time should be the shortest. Since, it is directly related to the time in which a product is manufactured. Another criterion concerns the costs of the osmotic solution. These costs should be the lowest possible. No symbols of those criteria were introduced because they are directly related to suitable single decision variables (Bartosik et al., 2011; Plawgo et al., 2009). 
Ondrej Ponjičan et al.

\section{Results and discussion}

Osmotic dehydration is a multidirectional mass exchange process, which is influenced by many factors. Kinetics of this process is described, as a rule, as water loss (WL), solid gain (SG), (Shi, 2008). Along with the increase of osmotic solution concentration and extension of duration of the dehydration process, conditions of mass exchange towards the increase of its intensity, change. It influences the reduction of water content (WL) and permission of the osmotic substance (SG) in the dehydrated plant raw material.

In osmotically dehydrated plums in the sucrose solution, the value of coefficient of mass transition depended on the solution concentration and duration of the process (Table 1). Together with the increase of the concentration of sucrose and extension of dehydration time the increase of the mentioned indicators took place.

The ratio of water loss and increment of dry substance growth (WL/SG) is one of the indicators used for assessment of the osmotic dehydration efficiency. It is desirable that considerable water content takes place at a small permission of osmotic substance. High values of this indicator show a good effectiveness of the dehydration process (Kowalska and Lenart, 2001). The best effectiveness of osmotic dehydration (WL/SG) was obtained with the use of sucrose solution with concentration of $65 \%$ and the least effective was the process with the use of syrup with the concentration of $35 \%$ (table 1.). After 90 minutes, the value of ratio (WL/SG) in case of samples dehydrated in $65 \%$ solution of sucrose was -2.50 at the concentration of $35 \%-2.30$. Extension of dehydration time to 180 minutes influenced a slight increase of osmotic dehydration efficiency coefficient respectively for fruit dehydrated in $65 \%$ solution $-2.258,35 \%-2.32$.

Table 1 .

The values of mass transfer coefficients in plums osmotically dehydrated in sucrose solutions

\begin{tabular}{|c|c|c|c|c|c|c|c|c|c|c|}
\hline \multirow{3}{*}{$\begin{array}{l}\text { Osmotic solu- } \\
\text { tion concen- } \\
\text { tration }(\%)\end{array}$} & \multirow{2}{*}{\multicolumn{2}{|c|}{$\begin{array}{c}\text { WL } \\
\left(\mathrm{g} \mathrm{H}_{2} \mathrm{O} / \mathrm{g} \text { p.s.m. }\right) \\
\text { Dehydration } \\
\text { time (min) }\end{array}$}} & \multirow{2}{*}{$\bar{X}$} & & \multirow{2}{*}{\multicolumn{2}{|c|}{$\begin{array}{c}\mathrm{SG} \\
\frac{\text { (g s.m./g p.s.m.) }}{\text { Dehydration time }} \\
\text { (min) }\end{array}$}} & \multirow{3}{*}{$\bar{x}$} & \multicolumn{2}{|c|}{ WL/SG } & \multirow{3}{*}{$\overline{\mathrm{X}}$} \\
\hline & & & & & & & & \multicolumn{2}{|c|}{$\begin{array}{l}\text { Dehydration } \\
\text { time (min) }\end{array}$} & \\
\hline & 90 & & 180 & & 90 & 180 & & 90 & 180 & \\
\hline 35 & 0.90 & & 1.11 & 1.01 & 0.39 & 0.48 & 0.44 & 2.30 & 2.32 & 2.31 \\
\hline 45 & 1.24 & & 1.41 & 1.33 & 0.53 & 0.60 & 0.57 & 2.33 & 2.35 & 2.34 \\
\hline 55 & 1.74 & & 2.13 & 1.94 & 0.73 & 0.88 & 0.81 & 2.38 & 2.42 & 2.40 \\
\hline 65 & 2.86 & & 3.48 & 3.17 & 1.14 & 1.35 & 1.25 & 2.50 & 2.58 & 2.54 \\
\hline $\bar{X}$ & 1.69 & & 2.03 & 1.86 & 0.70 & 0.83 & 0.77 & 2.38 & 2.42 & 2.40 \\
\hline NIR concentration & \multicolumn{4}{|c|}{0.083} & \multicolumn{3}{|c|}{0.053} & \multicolumn{3}{|c|}{0.012} \\
\hline NIR time & \multicolumn{4}{|c|}{0.059} & \multicolumn{3}{|c|}{0.037} & \multicolumn{3}{|c|}{0.008} \\
\hline $\begin{array}{l}\text { NIR concentration } \\
\text { time }\end{array}$ & \multicolumn{3}{|c|}{0.117} & & \multicolumn{2}{|r|}{0.037} & & \multicolumn{3}{|c|}{0.016} \\
\hline
\end{tabular}

Explanatory notes:

$\overline{\mathrm{X}}$ - mean value; NIR - least significant difference at $\mathrm{p}=0.05$. 
Optimisation of osmotic...

The efficiency of the process (WL/SG) in plums dehydrated in lower concentration of osmotic solution (35-45\%) within the range of 90-180 minutes was at a similar level (2.302.35). It was observed that double extension of the time of contact of fruit with a dehydrated medium does not considerably affect the process efficiency like the concentration of osmotic solution which was proved by Mayor et al., and Sereno et al., who investigated kinetics of osmotic dehydration of apples and pumpkin (Mayor et al., 2006; Sereno et al., 2001).

Each cultivar of fruit has a specific water, sugar, acids content. Moreover, it has individual mechanical properties, structure, and firmness of pulp. These features influence water content reduction, osmotic substance permission degree and physical properties of the chemical composition of osmotically dehydrated plums (Barat et al., 2001; Kowalska and Lenart, 2001). The final product obtained as a result of osmotic dehydration has a reduced water content and higher content of dry mass. Organic acids and other low-particulate substances soluble in water are removed together with water from fruit (mineral compounds, vitamins, colorants, simple sugars). While, the osmotic substance that permeate the plant tissue causes higher concentration of carbohydrates (Kowalska and Lenart, 2001; Kowalska, 2006; 2009).

Table 2.

Value of selected physical and chemical indicators of osmotically dehydrated plums in sucrose solutions

\begin{tabular}{|c|c|c|c|c|c|c|c|c|c|}
\hline \multirow{4}{*}{$\begin{array}{l}\text { Osmotic solution } \\
\text { concentration }(\%)\end{array}$} & \multicolumn{9}{|c|}{ Content $(\%)$} \\
\hline & \multicolumn{2}{|c|}{ Dry matter } & \multirow{3}{*}{$\overline{\mathrm{x}}$} & \multicolumn{2}{|c|}{ Extract } & \multirow{3}{*}{$\bar{x}$} & \multirow{2}{*}{\multicolumn{2}{|c|}{$\begin{array}{l}\text { Reducing sacchari- } \\
\text { des }\end{array}$}} & \multirow{3}{*}{$\bar{x}$} \\
\hline & \multicolumn{2}{|c|}{$\begin{array}{c}\text { Dehydration time } \\
(\mathrm{h})\end{array}$} & & \multicolumn{2}{|c|}{$\begin{array}{l}\text { Dehydration } \\
\text { time }(\mathrm{h})\end{array}$} & & & & \\
\hline & 1.5 & 3.0 & & 1.5 & 3.0 & & 1.5 & 3.0 & \\
\hline 35 & 11.65 & 12.50 & 12.08 & 9.00 & 10.00 & 9.50 & 8.90 & 9.71 & 9.31 \\
\hline 45 & 13.00 & 13.70 & 13.35 & 10.50 & 11.27 & 10.89 & 10.05 & 10.78 & 10.42 \\
\hline 55 & 15.00 & 16.56 & 15.78 & 12.00 & 13.45 & 12.73 & 11.88 & 13.00 & 12.44 \\
\hline 65 & 19.50 & 22.00 & 20.75 & 16.00 & 16.67 & 16.34 & 15.73 & 16.20 & 15.97 \\
\hline$\overline{\mathbf{x}}$ & 14.79 & 16.19 & & 11.88 & 12.85 & & 11.64 & 12.42 & \\
\hline NIR concentration & & 0.3278 & & & 0.2138 & & & 0.2320 & \\
\hline NIR time & & 0.4635 & & & 0.3024 & & & 0.3280 & \\
\hline NIR concentration time & & 0.5791 & & & 0.1159 & & & 0.4458 & \\
\hline
\end{tabular}

Explanatory notes:

$\overline{\mathrm{X}}$ - mean value; NIR - least significant difference at $\mathrm{p}=0.05$.

In osmotically dehydrated plums, the content of dry substance, extract and reducing saccharides depended statistically significantly on the concentration of sucrose solution and on the duration of the process. Along with the increase of the concentration of osmotic solutions and extension of the time of contact of fruit with sucrose syrup, the content of the mentioned elements increased (Table 2.). The increase of dry mass of a substance, which resulted from the concentration of extract elements and osmotic substance depended on both the amount of the removed water and permeating sucrose. Comparable results were presented by Barat et al., Lazarides et al., and Rastogii Raghavaro showing that a higher concentration of the osmotic solution preconditions obtaining of a higher driving force of the process. The increased 
permeating of the osmotic substance to the dehydrated material, particularly to superficial layers, may affect and lead to formation of a barrier impeding a transfer of mass between a plant tissue and solution (Barat et al., 19981; Lazarides, 1995, Rastogi and Raghavarao, 2004).

Obtained experimental results of physico-chemical tests served then to carry out the optimisation process. A collection of the settings of the dehydration process was selected as a collection of decision variables. This collection includes:

- Osmotic dehydration time $x_{1}$,

- Osmotic solution concentration $x_{2}$

Limitations imposed on decision variables

$$
\begin{gathered}
x_{1} \in\langle 1,5 ; 3,0\rangle[h] \\
x_{2} \in\langle 0,35 ; 0,65\rangle
\end{gathered}
$$

Scalar criterion of optimisation takes the following form:

$$
f_{c e l}=w_{o g} \cdot f_{\text {jakosć }}+\left(1-w_{\text {og }}\right) \cdot f_{\text {koszty }}
$$

It consists of two modules. The first one is the quality criteria:

$$
f_{\text {jakosć }}=\sum_{i=1}^{4} w j_{i} \cdot f_{\text {cel_ }^{i}}
$$

The second module is the cost criteria:

$$
f_{\text {koszty }}=\sum_{i=5}^{6} w k_{i} \cdot f_{\text {cel_}_{-} i}
$$

where:

$$
\begin{gathered}
f_{\text {cel } i}=\frac{k_{i} \max -k_{i}\left(x_{1}, x_{2}\right)}{k_{i} \max -k_{i} \min } \text { for }{ }^{i=1,2,3,4} \\
f_{\text {cel_ }_{-}}=\frac{x_{i}-x_{i} \min }{x_{i} \max -x_{i} \min } \text { for } i=1,2 \\
\sum_{i=1}^{4} w j_{i}=1 \\
\sum_{i=5}^{6} w k_{i}=1 \\
w_{\text {og }} \in\langle 0 ; 1\rangle
\end{gathered}
$$


Optimisation of osmotic...

The idea of the objective function consisted in minimization of the difference between expected values of criteria and the value of these criteria obtained based on experimental results.
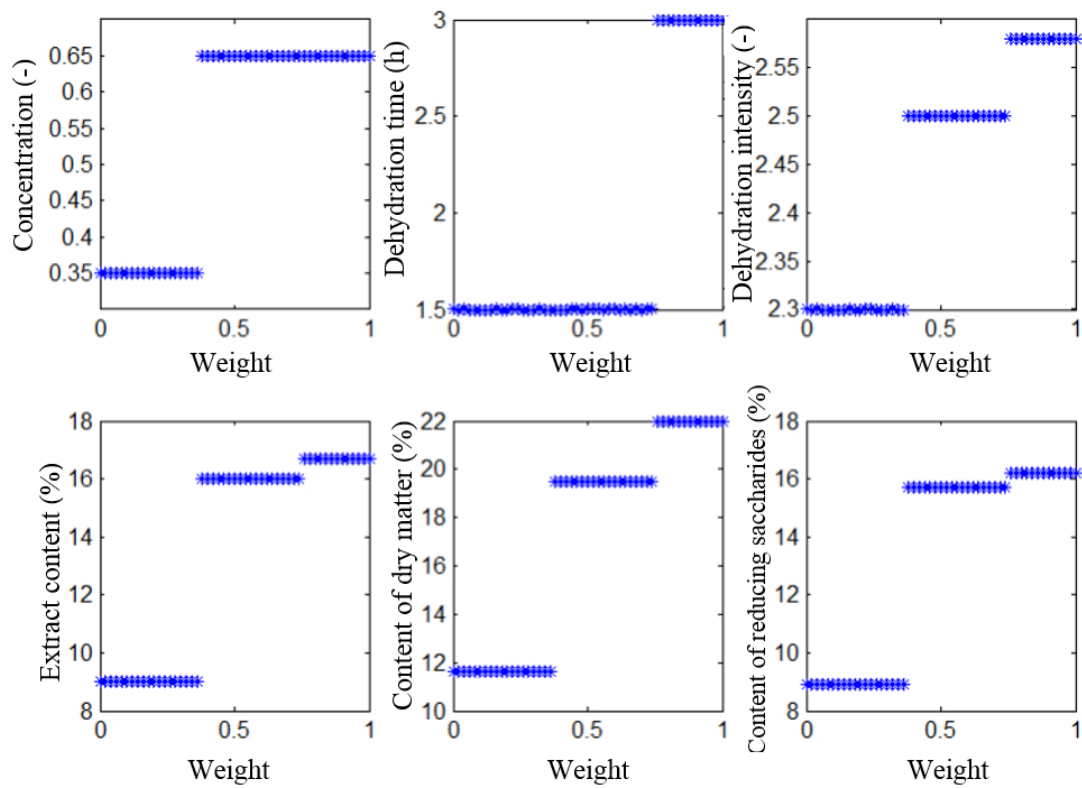

Figure 1. Criteria of quality and cost as a function of total weight

Function $f_{\text {jakośćc }}$ expresses a distance between point $\left(k_{1_{-} o}, k_{2_{-} o}, k_{3_{-} o}, k_{4_{-}}\right)$, and point $\left(k_{1}, k_{2}\right.$, $\left.k_{3}, k_{4}\right)$ which is placed on the hypersurface of admissible criteria values. Function $f_{\text {cost }}$ expresses distance between the point with coordinates $\left(x_{1 \min }, x_{2 \min }\right)$, and point $\left(x_{1}, x_{2}\right)$ which belongs to the decision variables space. Searching for the minimum of the objective function was determined with the use of Matlab program. The presented coefficients of weight $w_{i}$ served for including subjective mutual significance of the assessment criteria.

Relations of quality and cost criteria as a function of the total weight were presented on diagram in figure 1 . For quality criteria $\left(w_{j}\right)$ of quality significance they are 0.25 each, while cost weights 0.5 .

Figure 2 presents a relation of the main value of the objective function as a function of the total weight. The total weight amounting to 0 corresponds to a case of minimisation of the main value of the aim function due to the costs regardless the quality. Weight equal 1 contrary.

Figure 3 presents the function relations of quality and cost criteria as a function of the total weight and cost weight. Quality weights are 0.25 each. 
Ondrej Ponjičan et al.

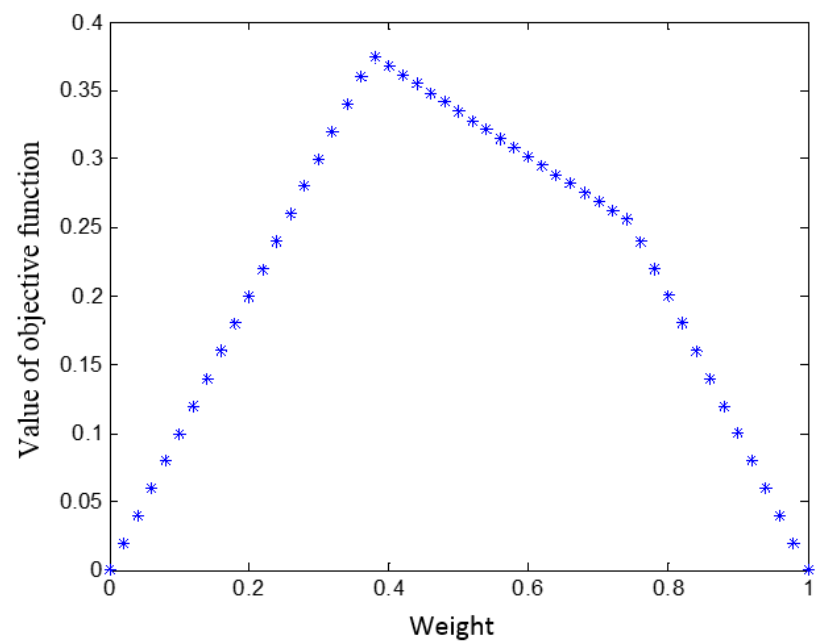

Fig. 2. Dependence of main objective function as a function of total weight
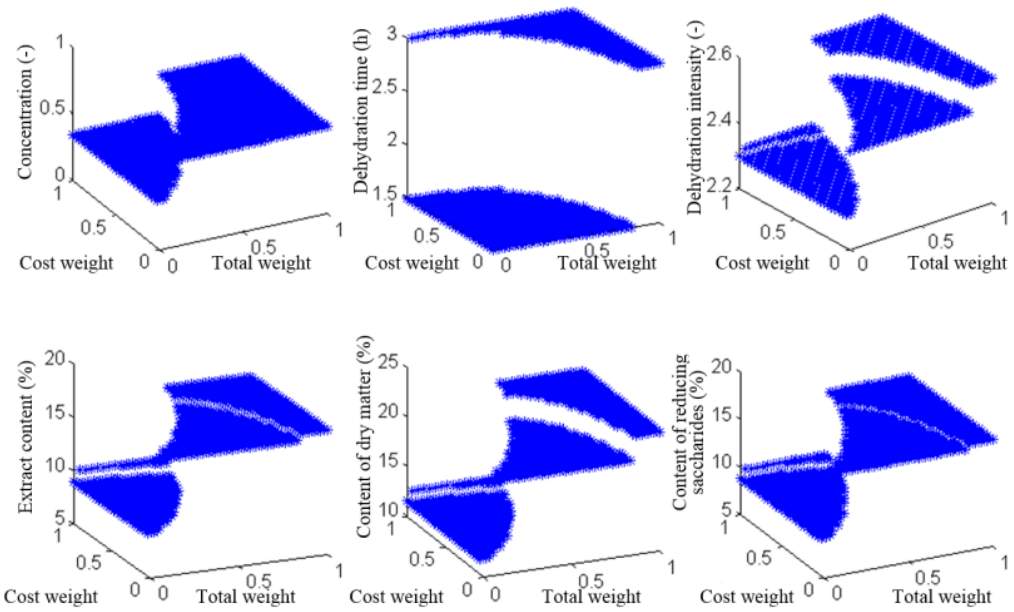

Figure 3. Dependence of quality and cost criteria as a function of total weight and cost weight 
Optimisation of osmotic...

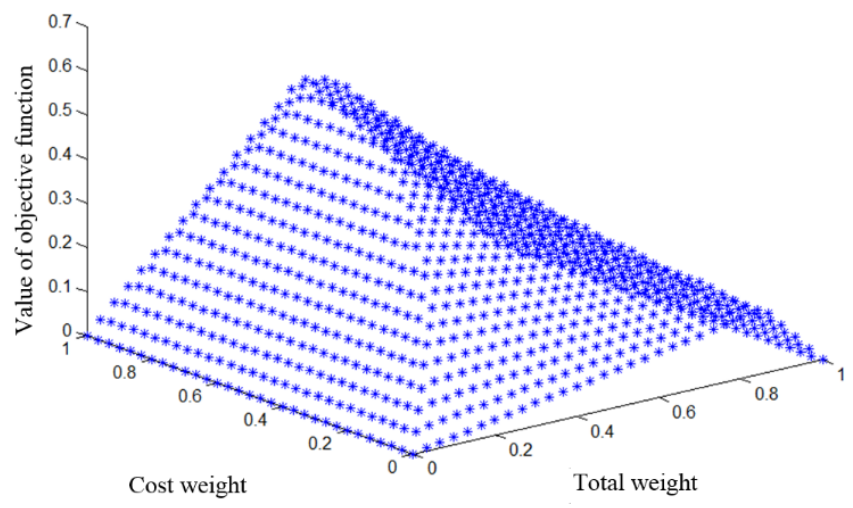

Figure 4. Dependence of value of objective function as a function of total weight and cost weight

Figure 4 presents a relation of the objective function value as a function of the total weight and cost weight for the determined quality weights $w_{j} 0.25$ each. Polyoptimisation algorithm and application in Matlab program presented in the paper enable determination of the set of values of non-dominated decision variables in the investigated process of osmotic dehydration. However, it depends on the decision-maker, which solution they will choose, and the presented schematic representation of the proceeding should be treated only as a tool that supports the decision-making process.

\section{Conclusions}

1. Parameters of osmotic dehydration had a significant impact on coefficients of mass exchange and physico-chemical indicators of fruit - along with the increase of concentration of osmotic solution and extension of the time of the process, the increase of the investigated sizes was observed.

2. For the assumed scalar criterion of optimisation, a manifest relation between a quality and product cost was shown. It was proved that combination of a linear additive scalar function with Euclidian metrics from a multidimensional space, gives an opportunity to control distances between points of these spaces in a few spaces at the same time.

\section{References}

Barat, J.M., Chiralt, A., Fito, P. (1998). Equilibrium in cellular food osmotic solution systems as related to structure. Journal of Food Science, 63(5), 836-840.

Barat, J.M., Chiralt, A., Fito, P. (2001). Modelling of simultaneous mass transfer and structural changes in fruit tissues. Journal of Food Engineering, 49(2/3), 77-85.

Bartosik, P., Plawgo, A., Kukiełka, L. (2011). Optymalizacja statyczna procesu odwadniania osmotycznego i przechowywania truskawek. Inżynieria Rolnicza, 5(130), 15-21.

Bekele, Y., Ramaswamy, H. (2010). Going beyond conventional osmotic dehydration for quality advantage and energy savings. Etiophian Journal of Applied Science and Technology, 1(1), 1-15. 
Ondrej Ponjičan et al.

Escriche, I., Chiralt, A., Moreno, J., Serra, J.A. (2000). Influence of blanching-osmotic dehydration treatments on volatile fraction of strawberries. Journal of Food Science, 65, 107.

Gruda, Z., Postolski, J. (1999). Zamrażanie Żywności. WNT, Warszawa. ISBN 83-204-2332-5

Kowalska, H., Lenart, A. (2001). Mass exchange during osmotic pre-treatment of vegetables. Journal of Food Engineering, 49(2/3), 137-140.

Kowalska, H. (2009). Wpływ stężenia roztworu, temperatury i czasu procesu na odwadnianie osmotyczne jabłek. Żywność. Nauka. Technologia. Jakość, 1(62), 73-85.

Kowalska, H. (2006). Kinetyka osmotycznego odwadniania dyni. Żywność. Nauka. Technologia. Jakość, 2(47), 135-142.

Lazarides, H.N., Katsanidis, E., Nickolaidis, A. (1995). Mass transfer kinetics during osmotic preconcentration aiming at minimal solid uptake. Journal of Food Engineering, 25, 151-166.

Matusek, A., Meresz, P. (2002). Modelling of sugar transfer during osmotic dehydration of carrots Periodica Polytechnica. Chemical Engineering, 1(2), 83-92.

Mayor, L., Moreira, R., Chenlo, F., Sereno, A.M. (2006). Kinetics of osmotic dehydration of pumpkin with sodium chloride solutions, Journal of Food Engineering, 74(2), 253-262.

Panagiotou, N.M., Karathanos, V.T., Maroulis, Z.B. (1999). Effect of osmotic agent on osmotic dehydration of fruits. Drying Technology, 17, 175-189.

Plawgo, A., Szparaga, Ł., Bartosik, P., Kubiak, M. S. (2009). Static optimization of osmotic dehydration and storage process of previously frozen plums. [w]: Food Technology Opertaions. New Vistas. Red. W. Kopeć i M. Korzeniowska. Wyd. Uniwersytetu Przyrodniczego, Wrocław, 233-241.

Rahman, M.S., Perera, C.O. (2007). Drying and food preservation. W: Handbook of food preservation Red. M.S. Rahman, CRC Press, USA, 412.

Rastogi, N.K., Raghavarao, K.S.M.S., Niranjan, K., Knorr, D. (2002). Recent developments in osmotic dehydration: methods to enhance mass transfer. Trends in Food Science Technology, 2(13), 48-59.

Rastogi, N.K., Raghavarao, K. (2004). Mass transfer during osmotic dehydration of pineapple: consideringFickian diffusion in cubical configuration. Food Science and Technology, 37, 43-47.

Sereno, A.M., Moreira, R., Martinez, E. (2001). Mass transfer coefficients during osmotic dehydration of apple in single and combined aqueous solutions of sugar and salt. Journal of Food Engineering, 47(1), 43-49.

Shi, J. (2008). Osmotic dehydration of foods. W: Food Drying Science and Technology: Microbiology, Chemistry, Applications. Red. Y.H. Hui, C. Clary, M.M. Farid, O.O. Fasina, A. Noomhorm, J. Welti-Chanes. DEStech Publications, Pennsylvania, U.S.A, 275-295.

Soliva-Fortuny, R.C., Belloso, O.M. (2003). New advances in extending the shelf-life of fresh-cut fruits: a review. Trends in Food Science Technology, 14, 341-353.

Tarnowski, W. (2011). Optymalizacja i polioptymalizacja $w$ technice. Wyd. Uczelniane Politechniki Koszalińskiej, Koszalin, ISBN 978-83-7365-273-6 
Optimisation of osmotic...

\section{OPTYMALIZACJA PROCESU ODWADNIANIA OSMOTYCZ- NEGO ŚLIWEK}

Streszczenie. W pracy określono kinetykę procesu odwadniania osmotycznego śliwek w zależności od czasu obróbki i stężenia roztworów sacharozy. Głównym celem przeprowadzonych badań była polioptymalizacja procesu utrwalania, czyli dobór optymalnych parametrów procesu odwadniania osmotycznego z uwzględnieniem zmian wybranych wskaźników jakości. Zdefiniowanie optymalnych warunków całego toku utrwalania może wskazać możliwości ograniczenia zużycia środków utrwalających (substancji osmotycznych) oraz obniżenia zapotrzebowania na energię. Na podstawie przeprowadzonych badań stwierdzono, że parametry procesu odwadniania osmotycznego miały istotny wpływ na współczynniki wymiany masy i wskaźniki fizykochemiczne owoców - wraz ze zwiększeniem stężenia roztworu osmotycznego i wydłużeniem czasu procesu obserwowano zwiększenie badanych wielkości. W drugiej części pracy przeprowadzono optymalizację procesu utrwalania owoców. Idea funkcji celu polegała na minimalizowaniu różnicy pomiędzy oczekiwanymi wartościami kryteriów, a wartością tych kryteriów otrzymanych na podstawie eksperymentalnych wyników. Dla przyjętego skalarnego kryterium optymalizacji pokazana została jawna zależność pomiędzy jakością, a kosztami produktu.

Słowa kluczowe: śliwki, odwadnianie osmotyczne, kinetyka, optymalizacja.

Identification data Authors:

Ondrej Ponjičan

Aleksandar Sedlar

Pavol Findura https://orcid.org/0000-0001-6050-4647

Agnieszka Szparaga https://orcid.org/0000-0001-9153-7783

Stawomir Kocira https://orcid.org/0000-0002-2888-3023 